\title{
A Qualitative Course-Based Inquiry into Child and Youth Care Students' Insights Concerning the Theoretical Frameworks that Guide their Efforts to Form Meaningful Connections with Children, Youth, and Families
}

DOI: https://doi.org/10.47175/rissj.v3i1.391

\section{| Jadyn Adams ${ }^{1}$ | Shaelyn Korpach ${ }^{2}$ | Payton O'Keefe ${ }^{3}$ | | Cheyanne Soetaert ${ }^{4}$ | Gerard Bellefeuille ${ }^{5, *}$ |}

\author{
1,2,3,4 Bachelor of Child and \\ Youth Care, MacEwan \\ University, Edmonton, \\ Alberta, Canada \\ ${ }^{5}$ Professor of Child and Youth \\ Care, MacEwan University, \\ Edmonton, Alberta, Canada \\ *bellefeuilleg@macewan.ca
}

\begin{abstract}
The purpose of this course-based inquiry was to gain insight into how child and youth care (CYC) students apply theoretical frameworks in their connection-building efforts with children and youth. A qualitative research design was chosen for the purpose of capturing the lived experiences of the CYC student participants. The findings presented in this study revealed three overarching themes: a) provides pathways of understanding, b) all about building trust, and c) feeling understood and accepted. KEYWORDS

Child and Youth Care; Connection: Course-Based; theory; qualitative
\end{abstract}

\section{INTRODUCTION}

Learning how to form purposeful and compassionate relationships with children and youth is at the core of a child and youth care (CYC) education (Bellefeuille \& Jamieson, 2012; Fewster, 1990; Garfat, 2008; Gharabaghi, 2014; Krueger, 2004; Ricks, 2003; Smith, 2001). Like seafarers navigating the seas, we as CYC students engage in a four-year educational voyage, during which we absorb various human development theories and conceptual frameworks so that we can acquire the skills and knowledge required to form positive and helpful connections with children and youth. Setting sail from course to course, we find ourselves immersed in the riptides of taking in new information concerning the nature of the "self" as a relational being and letting go of old ways of thinking of human beings as autonomous, ego-based individuals. Considering that CYC practice is, first and foremost, about building meaningful connections with children and youth as a means by which to achieve meaningful therapeutic gains can be attained, we became curious as to how CYC students apply theory develop into their relational practice. More specifically, the focus of our course-based study was on identifying which of the theoretical frameworks to which CYC students are introduced influence their ability to connect with children, youth, and families.

\section{RESEARCH METHODS}

\section{Undergraduate Course-Based Research}

The Bachelor of CYC program at MacEwan University is always seeking additional pedagogic methods to promote basic considering, reflection, and praxis as crucial components of the overall understudy instructive involvement. As such, a course-based inquire about approach to investigate strategies instruction offers understudies the opportunity to ended up talented in fundamental investigate abilities by conceptualizing, constructing, overseeing, and showcasing small-scall investigate ventures beneath the 
course and supervision of the course instructor-commonly, a teacher with an broad foundation in investigate and teaching.

Course-based inquire about in higher instruction educate has developed significantly in later a long time (Allyn, 2013; Bellefeuille, Ekdahl, Kent, \& Kluczny, 2014; Harrison, Dunbar, Ratmansky, Boyd, \& Lopatto, 2010). The esteem picked up from a course-based approach to educating inquire about strategies is critical for understudies. To begin with, there's justify in advertising understudies true learning encounters that improve the exchange of information learned in conventional instruction hone. For illustration, previous understudies have passed on that their support in course-based inquire about empowered them to develop their logical information by receiving modern strategies of inventive request. Moment, course-based inquire about offers understudies the opportunity to work with teaches in a mentoring relationship. Third, discoveries created through course-based investigate can sometimes be

\section{Research Design}

Investigating how CYC students at MacEwan University consciously apply theory in their practice to form meaningful connections with children, youth, and families required a methodology that best captured the subjective nature of the phenomenon under investigation. As stated by Mills, Bonner, and Francis (2006), "researchers must select a investigate worldview that's compatible with their convictions around the nature of reality" (p.2). It was therefore imperative that we identified a paradigm that best suited our research question. Denzin and Lincoln (2005) refer to research paradigms as the "net" of ontological, epistemological, and methodological beliefs and assumptions that a researcher relies on to generate knowledge (p. 183). For the purposes of this course-based study article, we constructed our qualitative research design based on the interpretive paradigm. Interpretivist inquiry is expressively associated with qualitative designs in that it focuses on the meaning-making practices of research participants (Creswell, 2013; Denzin \& Lincoln 2011) to obtain in-depth information about a phenomenon regarding which not much is known or to provide new perspectives are (Holloway \& Wheeler, 2013).

\section{Research Question}

Our main research question was as follows: What are the insights of CYC students concerning the theoretical frameworks that are taught in the CYC program with regard to how these students form meaningful connections with children, youth, and families?

\section{Sampling Strategy}

We employed a non-probability purposive sampling strategy to recruit participants from all four years of the CYC program of study at MacEwan University. Non-probability purposive sampling is defined as the process of selecting research participants based on specific purposes with the goal of answering the study's research question (Creswell \& Poth, 2018; Crotty, 1998). Our choice of members was subsequently guided by the have to be collect data that was germane to replying our investigate questions, and we concluded that CYC students currently practicing in the field would be the most appropriate sources of this information.

\section{Data Collection Strategy}

Our primary data collection strategy was an open-ended questionnaire distributed via email. The use of e-mail to distribute the questionnaire was a suitable choice for a number of reasons. Firstly, given the social distancing requirements introduced due to the COVID- 
19 pandemic, we had to adopt a remote data collection strategy, and, secondly, we had a short period of time in which to collect our data. Open-ended questionnaires are considered to be an efficient data collection method (Babbie, 2011; Denzin \& Lincoln, 2011). Unlike closed-ended questions, which result in limited and narrow responses to questions, the use of an open-ended questionnaire allowed us to probe deeply into the participants' answers and gain valuable information about their experiences of using theory to form meaningful connections with children and youth.

\section{Arts-Based Activity}

In addition to completing the open-ended text format questionnaire, participants were asked to attach an image, song, poem, or drawing that illustrated the theoretical influence behind their efforts to form meaningful connections with children and youth. The potential of arts-based methods as an approach by which to understand, represent, and challenge the complexity of human experiences is increasingly being recognized (McNiff, 2007). Implicit in the arts-based research method is the ontologically and epistemologically intersubjective ways of being and knowing inherent in the interpretive research paradigm (Barone \& Eisner, 2012; Chilton, Gerber, \& Scotti, 2015).

\section{RESULT AND DISCUSSION}

\section{Data Analysis Strategy}

We selected Braun and Clarke's (2006) inductive approach to thematic analysis as our information examination procedure since it networks well with the interpretive viewpoint that we grasped in our course-based inquire about venture. From the data analysis, three main themes were extracted: a) provides pathways of understanding, b) all about building trust, and c) fosters belonging.

\section{Findings}

a) Provides Pathways of Understanding

The participants identified a total of 21 different theoretical frameworks as being important in terms of how they relate to children and youth. For some participants, the greatest impact of the theoretical frameworks taught in CYC education lay in increasing their sensitivity to one's "life space." For example, one participant commented on how these theories had allowed them to "gain perspective on the social, cultural and historical factors that may affect an individual." In practice, this participant "aim[s] to facilitate safe and meaningful conversations that offer individuals an opportunity to share their stories." Another participant noted how "an approach that focuses on life space work and meeting the child where they are at physically, mentally, and emotionally can help form deeper connections with children and youth." This participant explained how this approach may take the form of "something as simple as playing a game with a child," which allows a practitioner to connect through an activity the child already relates to and enjoys." Essentially, life space intervention involves the intentional use of the everyday opportunities that present themselves in the spaces where the lives of children and youth unfold. Life space work is largely based on the assumption that children and youth often learn best "in the moment." As a result, life space intervention is about meeting children and youth where they are at developmentally.

\section{b) All About Building Trust}

The participants identified trauma-informed care, strength-based practice, and developmental theories as the three theoretical frameworks that had the most influence on 
their practice. All three theoretical frameworks stress the importance of establishing trust, empathy, and understanding. For example, one participant commented that they use a trauma-informed approach to be "cautious of past and present trauma to remain as empathetic as possible while inserting [themselves] into an individual's life space as a positive and safe person." Another participant stated that they utilize a strength-based and developmentally appropriate approach in practice by "identifying the strengths of those [they] work with so [they] can meet children and youth where they are at, rather than placing unrealistic expectations" that may harm the developing relationship. This participant went on to explain that this approach establishes trust, as they "work with the person in a collaborative manner to achieve he goals that the child or youth has set," thus establishing a person-centered practice.

\section{c) Feeling Understood and Accepted}

The final dominant theme was how the use of the theoretical frameworks discussed above provided a skill set with which CYC practitioners could foster a sense of being understood and accepted. Several participants commented that children and youth often feel isolated and alone. For example, one participant commented on how they used trauma-informed knowledge and a relational approach to communicate to children and youth that they are "someone children and youth can lean on, play with, get mad at, and feel validated." Another participant noted that they use developmental theories "to create interventions or interactions based on their needs which range from basic safety and food to emotional connection and belonging." Ultimately, participants shared how these frameworks offer insight into the experiences of others, which allows practitioners to "relate to and be honest with the children, youth, and families [they] work with" and thus foster a sense of belonging.

\section{CONCLUSION}

This qualitative course-based study sought to answer the following question: What are the insights of CYC students concerning the theoretical frameworks that are taught in the CYC program with regard to how these students form meaningful connections with children, youth, and families? The findings of this course-based study provide insight into which theoretical frameworks taught in CYC education that CYC practitioners are currently using in their efforts to form meaningful connections with children and youth. The findings suggest that while CYC students are taught numerous theories and intervention frameworks over their four-year program of study, CYC educators cannot assume that these students apply what they are taught in the classroom in practice. This course-based study suggested areas that we can examine more critically and provides some evidence as to what theoretical frameworks undergraduate CYC students find helpful when applied in their practice.

\section{REFERENCES}

Allen, J. P., \& Manning, N. (Eds.). (2007). From safety to affect regulation: Attachment from the vantage point of adolescence. New Directions in Child and Adolescent Development, 117, 23-39.

Babbie, E. R. (2011). The basics of social research (5th ed.). Belmont, CA: Wadsworth.

Barone T., \& Eisner E. W. (2012). Arts-based research. Los Angeles, CA: Sage Publications, Inc. 
Bellefeuille, G., Ekdahl, C., Kent, L., \& Kluczny, M. (2014). A course-based creative inquiry approach to teaching introductory research methods in Child and Youth Care undergraduate education. International Journal of Teaching and Education, 2(2), 1-9.

Bellefeuille, G., \& Jamieson, D. (2012). Foreword. Expanding our creative potential: Looking beyond the traditional boundaries of child and youth care practice In G. Bellefeuille, D. Jamieson, \& F. Ricks (Eds.), Standing on the precipice: Inquiry into the creative potential of child and youth care practice (2nd ed.) (pp. 1-4). Edmonton, AB: MacEwan Press.

Chilton G., Gerber N., \& Scotti V. (2015). Towards an aesthetic intersubjective paradigm for arts-based research: an art therapy perspective. UNESCO Observatory MultiDisciplinary Journal in the Arts, 5(1), 1-27.

Creswell, J. W. (2013). Qualitative inquiry and research design: Choosing among five approaches (3rd ed.). CA: Sage: Thousand Oaks.

Creswell, J. W., \& Poth, C. N. (2018). Qualitative inquiry \& research design: Choosing among five approaches (4th ed.). Thousand Oaks, CA: Sage.

Crotty M (1998) The foundations of social research: Meaning and perspectives in the research process. St. Leonards, NSW: Allen \& Unwin.

Denzin, N. K., \& Lincoln Y. S. (Eds). (2011). The SAGE handbook of qualitative research (4th ed.). Thousand Oaks: Sage.

Fewster, G. (1990). Being in child care: A journey into self. New York: Haworth.

Garfat, T. (2008). The inter-personal in-between: An exploration of Relational Child and Youth Care practice, In G. Bellefeuille and F. Ricks, (Eds) Standing on the precipice: Inquiry into the creative potential of Child and Youth Care Practice, (pp 7-34), Alberta, Canada: MacEwan Press.

Gharabaghi, K. (2014) Relationships and relational practice. CYC-OnLine, 185, 6-9.

Harrison, M., Dunbar, D., Ratmansky, L., Boyd, K., \& Lopatto, D. (2011). Classroombased science research at the introductory level: Changes in career choices and attitude. CBE Life Sciences Education, 10(3), 279-286.

Holloway, I., \& Galvin, K. (2016). Qualitative research in nursing and health care (4th ed.). Blackwell Science.

Krueger M. (2004). Defining relational work. CYC-OnLine, 67. Retrieved from: http://www.CYC-net.org/CYC-online/CYCol-0408-krueger.html

Mills, J., Bonner, A., Francis, K. (2006). The development of constructivist grounded theory. International Journal of Qualitative Methods, 5(1), 1-10.

Ricks, F. (2003) Relatedness in Relationships: It's About Being. Relational Child and Youth Care Practice, 16(3) 70-77.

Smith, M. (2011). Love and the CYC relationship. Relational Child and Youth Care Practice, 24(1-2), pp. 205-208. 